\title{
LI-ION COTS CELLS FOR LOW TEMPERATURE MARS LANDERS
}

\author{
Rachel Buckle $^{(1)}$, Carl Thwaite ${ }^{(1)}$, Sanjay Vijendran ${ }^{(2)}$, Max Schautz ${ }^{(2)}$ \\ (1) ABSL Space Products, F4 Culham Science Centre, Abingdon, UK. Email: rachel.buckle@absl.enersys.com \\ (2) ESTEC, Keplerplaan, 1, 2201AZ Noordwijk, The Netherlands
}

\begin{abstract}
This digest describes the work undertaken to develop a secondary Li-ion battery for use in European space exploration missions from Commercial off the Shelf (COTS) cells. The battery was required to operate at temperatures below $-20^{\circ} \mathrm{C}$ and survive a freeze/thaw cycle.
\end{abstract}

A previous paper [1] described the search for a suitable cell, and the initial data from the module life test. As the results from this testing were extremely promising, the project was extended to determine the module performance up to $720 \mathrm{Sols}$ at $-20^{\circ} \mathrm{C}$.

Very low temperature survivability tests were also performed on the selected cells with good results. Further work has therefore been carried out to determine the longer term effects following a freeze/thaw cycle.

The final part of the project was to produce a performance model of the cells. Results from the simulations have been compared to test data for the selected cell type.

\section{INTRODUCTION}

Operation of rovers/landers on the Martian surface requires overcoming several operational barriers for the power system. The solar power is limited due to the distance from the sun and the prevalence of dust storms. Temperatures range from $-80^{\circ} \mathrm{C}$ on a summer night and $-130^{\circ} \mathrm{C}$ on a winter night, up to $+30^{\circ} \mathrm{C}$ at the equator in summer at noon [2]. These factors mean that power could be extremely limited and little thermal control available at times. Several means of generating electrical power, along with maintaining a suitable thermal environment, are available. These include solar arrays, nuclear systems and fuel cells.

As part of the Mars Robotic Exploration Preparation (MREP) programme, ESA is funding development of a low temperature Li-ion battery based on commercial cell technologies. The main objective of the project was to identify a COTS cell that would operate (charge and discharge) at a maximum temperature of $-20^{\circ} \mathrm{C}$. In addition, the cells needed to survive an emergency case with temperatures reaching as low as $-100^{\circ} \mathrm{C}$ for four weeks.
The previous paper presented an assessment of the operability of COTS Li-ion cells at low temperature for use on a Martian lander. Initially a market survey was conducted to down-select a number of cells for detailed testing. Four cell types were then tested to determine the cell discharge energy and voltage at the required temperature, the charge capability and life performance. From these data, the best performing cell-type was selected for module life testing.

The initial test data demonstrated that the selected cell type had low fade under the required charge/discharge profile up to $180 \mathrm{Sols}$, and was robust to very low temperature storage.

This paper presents further results from this low temperature COTS project. The module life test was extended to 720 Sols. In addition, the longer term effects of very low temperature storage at $-100^{\circ} \mathrm{C}$ were determined. An electrical model has also been constructed to predict the performance of this cell type under low temperature cycling. Comparative results from this work will be presented.

\section{BATTERY REQUIREMENTS}

The initial battery requirements for this project are based on a realistic mission specification from the European Space Agency (ESA); they are summarised in Table 1.

Table 1. Project battery requirements [3]

\begin{tabular}{|l|c|}
\hline Energy at EoL & $200 \mathrm{Wh}$ \\
\hline Energy density $\mathbf{a}-\mathbf{- 2 0}^{\circ} \mathbf{C}$ & $125 \mathrm{Wh} / \mathrm{kg}$ \\
\hline Average discharge voltage $\mathbf{a}-\mathbf{- 2 0}^{\circ} \mathbf{C}$ & $28 \mathrm{~V}$ \\
\hline Lowest temperature for charging & $-20^{\circ} \mathrm{C}$ \\
\hline Cycle requirement & $180 \mathrm{Sols}$ \\
\hline
\end{tabular}

Data from the end of the 180 Sols showed that the module had lost only $6 \%$ of the BoL capacity when measured at $-20^{\circ} \mathrm{C}$. The project was therefore extended with an updated goal of reaching 720 Sols.

\section{MODULE LIFE TEST}

\subsection{Test Description}

The selected cell type was built into an $8 \mathrm{~s} 8 \mathrm{p}$ module and tested at low temperature (minimum $-20^{\circ} \mathrm{C}$ cell 
temperature) and realistic rates. The module was sized using the information on charge/discharge rates, voltages and degradation determined in the cell selection testing [1].

The test profile is shown in Figure 1. Capacity checks at a chamber temperature of $-20^{\circ} \mathrm{C}$ were carried out before the cycle testing, at the end of the original 180 Sol requirement, and after the extended goal of 720 Sols was reached.

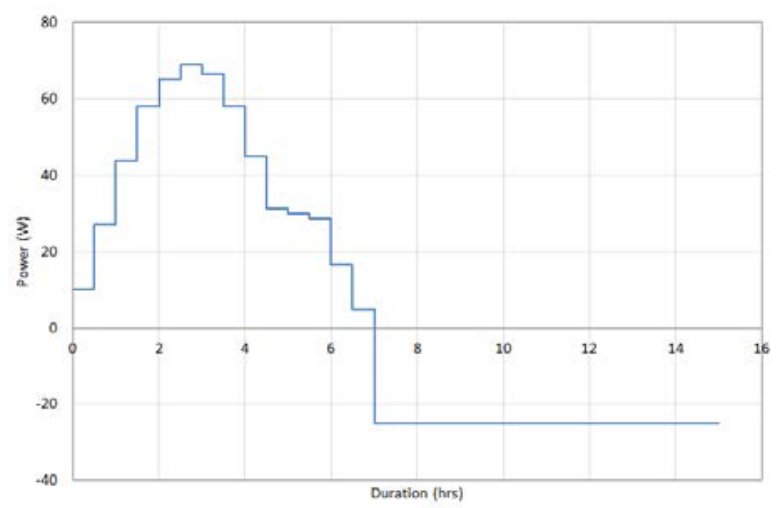

Figure 1. Power profile for module test

Unfortunately, between the end of the 180 Sols and the beginning of the life test extension, the thermal chamber failed, causing the temperature of the battery to rise above $0^{\circ} \mathrm{C}$. Although no water was observed on the module or in the connectors, several cells were found to be less than 3.0V (Figure 2). The resulting investigation determined that Cell 8 in String 7 had been shorted.

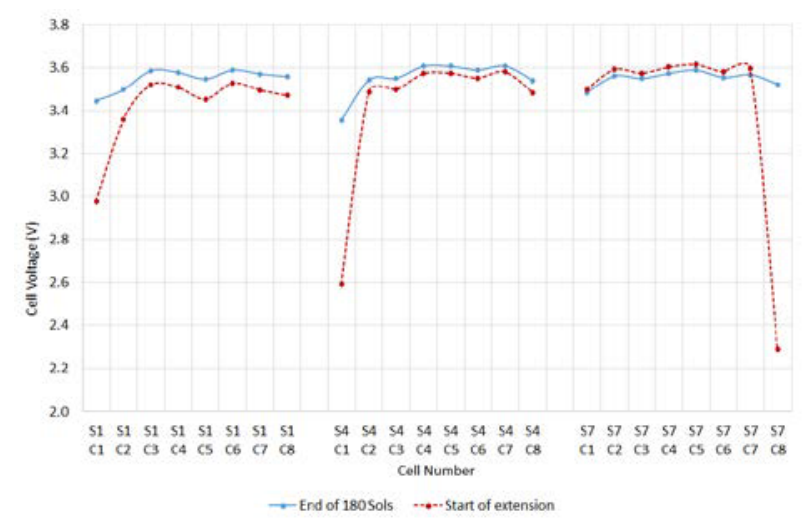

Figure 2. Mod\#1 cell open circuit voltages

As the cells are sensitive to low temperature, any failure in this module (Mod\#1) could be attributed to the test conditions, or the cell short. Therefore, to be able to confidently determine whether this cell type can perform 720 Sols at $-20^{\circ} \mathrm{C}$, a second module was built (Mod\#2) and cycled under the same regime. Therefore, results from both modules will be presented in this paper.

\subsection{Life Test Results}

The results from the capacity measurements are shown in Table 2. After cycling at $-20^{\circ} \mathrm{C}$ for 720 Sols, both modules have less than $15 \%$ fade. Mod\#1 has higher fade and a higher maximum dispersion at the end of discharge (EoD) than Mod\#2. This difference is likely due to the module short circuit. The measured data shows Mod\#1 lost 3\% capacity during the period between the end of 180 Sols and the start of the extension. In addition, the EoD voltage of the Mod\#1 at end of life (EoL) was higher than for Mod\#2, which restricted the measured capacity.

Table 2. Capacity measurement data

\begin{tabular}{|l|c|c|}
\hline & Mod\#1 & Mod\#2 \\
\hline Capacity loss & $15 \%$ & $10 \%$ \\
\hline Energy loss & $14 \%$ & $11 \%$ \\
\hline EoD dispersion String1 & $256 \mathrm{mV}$ & $672 \mathrm{mV}$ \\
\hline EoD dispersion String4 & $1110 \mathrm{mV}$ & $664 \mathrm{mV}$ \\
\hline EoD dispersion String7 & $364 \mathrm{mV}$ & $580 \mathrm{mV}$ \\
\hline
\end{tabular}

The discharge voltage during Mod\#1 capacity measurements at $-20^{\circ} \mathrm{C}$ are shown in Figure 3. At beginning of life $(\mathrm{BoL})$, the cells were more closely balanced than for later measurements, so all cells remained above $2.5 \mathrm{~V}$ during the discharge to $24 \mathrm{~V}$ (3.0 V/cell on average). As the cells aged, differences in the cells and the temperatures experienced meant that their resistance and/or capacity changed at different rates. In order to prevent cell over-discharge, the module discharge was limited by cell voltage. Therefore, as the dispersion increased, the module EoD voltage also increased, restricting the measured capacity.

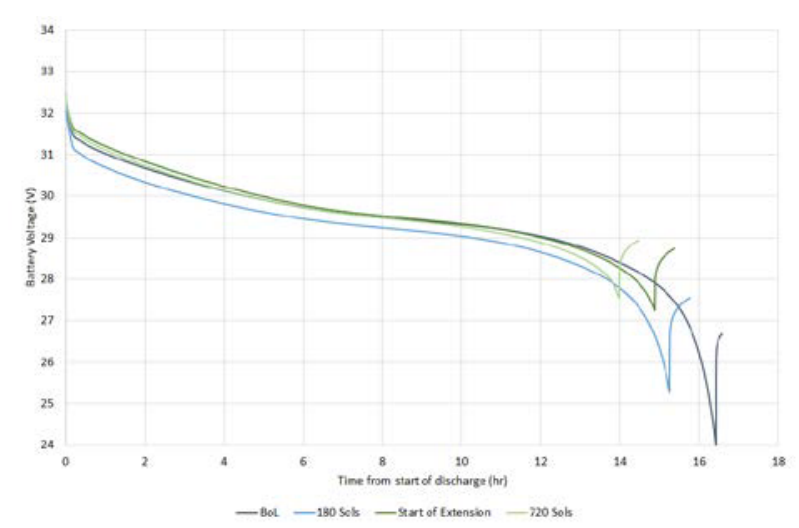

Figure 3. Mod\#1 discharge voltage curves $\left(-20^{\circ} \mathrm{C}\right)$

For comparison, the Mod\#2 capacity measurements at $-20^{\circ} \mathrm{C}$ are shown in Figure 4. This module shows different behaviour to Mod\#1, in that the capacity at EoL was not limited by cell dispersion. When the module was discharged to $24 \mathrm{~V}$, all cells in the 
monitored strings remained above $2.5 \mathrm{~V}$.

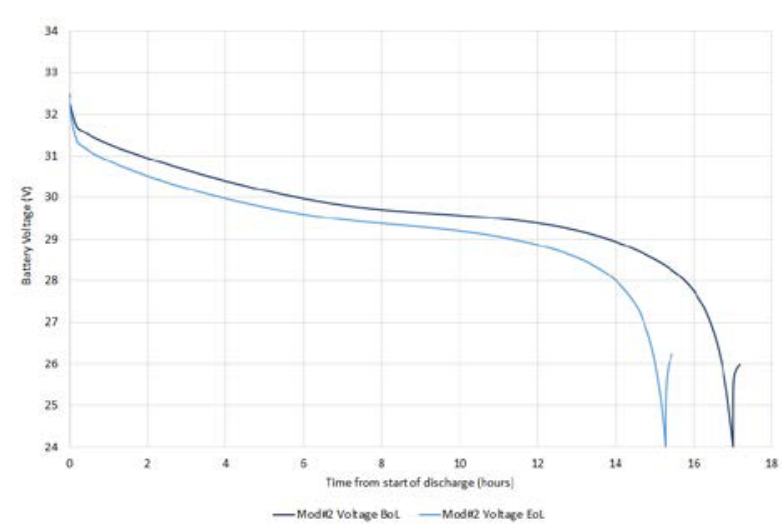

Figure 4. Mod\#2 discharge voltage curves $\left(-20^{\circ} \mathrm{C}\right)$

The EoD voltages for both modules throughout the full life test are shown in Figure 5. The 720 Sol requirement was met by both modules, with EoD voltages well above the $24 \mathrm{~V}$ minimum.

At the start of the test, Mod\#1 shows a significantly lower voltage than Mod\#2. This can be attributed to the temperature of the tests; Mod\#1 was around $4{ }^{\circ} \mathrm{C}$ colder (on average) than Mod\#2 during the first 180 Sols (Figure 9). For the remaining cycles, the voltages of both modules are very similar. The rate of decrease of the EoDV is comparable for both modules, with the actual voltage more affected by the test temperature than by the fade. Considering a cell in Mod\#1 was shorted twice, these results show the resilience of the cells, as well as the low level of fade and resistance increase of this cell type when cycled at low temperatures.

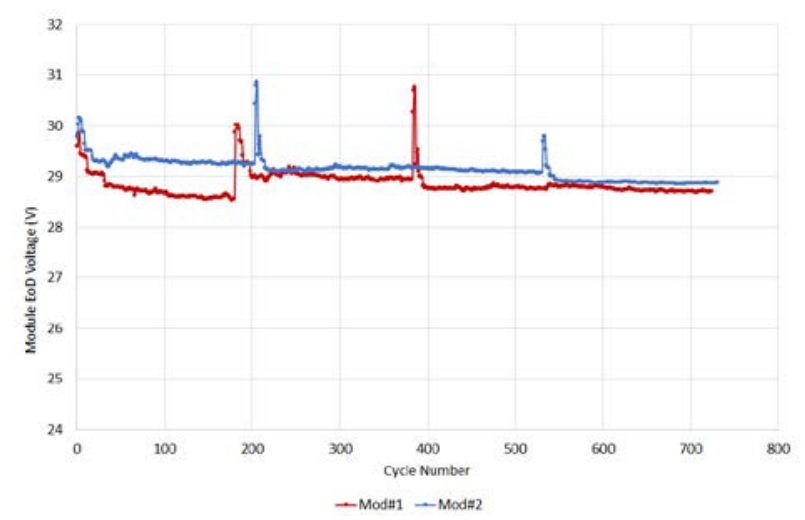

Figure 5. EoD voltages of Mod\#1 and Mod\#2

During the cycling there are several points at which the EoD voltages of both modules show sharp increases. For Mod\#1, the increase at 180 Sols corresponds with the end of the initial cycling requirement, and the restart of the test.

The next voltage spike, at 380 cycles for Mod\#1, occurred at the same time as the increase seen after 210 cycles for Mod\#2. The reason for these is another failure of the thermal chamber. The temperature again rose past $0^{\circ} \mathrm{C}$, with the consequent risk of condensation forming on the module. Results from Mod\#1 show that when the temperature started to rise, the cell dispersion initially reduced (Figure 6). This is expected, as the cell resistance will decrease. However after another two Sols, the dispersion in String 7 increased dramatically throughout the following cycle. When this increase occurred, the battery temperature was around $12^{\circ} \mathrm{C}$, so any ice in the chamber would be melting and a short circuit due to condensation was possible.



Figure 6. Mod\#1 battery temperature and cell dispersion during chamber failure

Unlike Mod\#1, no evidence of cell shorting could be seen on Mod\#2. There was no dramatic increase in the dispersion for any of the strings during cycling (Figure 7). This was expected, as Mod\#2 was equipped with IP67 rated connectors to prevent moisture ingress.

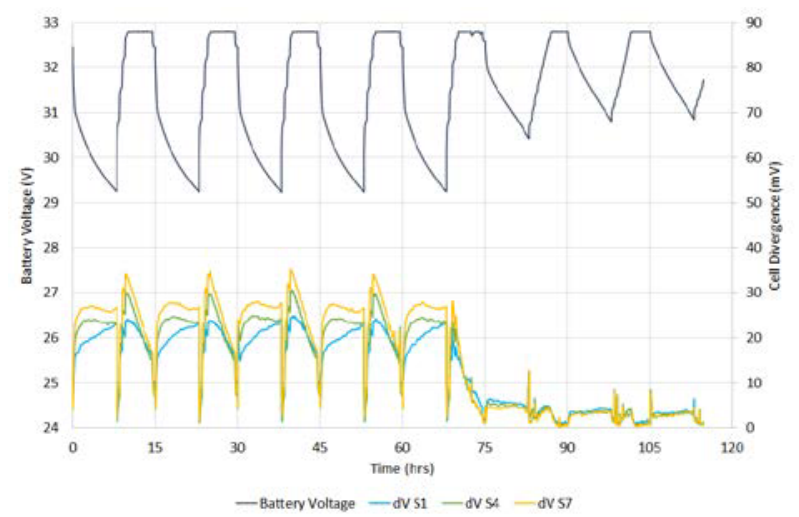

Figure 7. Mod\#2 battery voltage and cell dispersion during chamber failure

Due to the lack of balancing electronics on ABSL batteries, and the possibility of Li-plating on the cells if the EoC voltage increases sufficiently, the cell dispersion is an important factor. Figure 8 shows a comparison of the maximum EoC voltage dispersion for each monitored string in the two modules. Apart from 
String 7 on Mod\#1 (which contains the shorted cell), the remaining strings on both modules showed similar levels of dispersion increase, with the actual dispersion in the strings remaining below $50 \mathrm{mV}$ at EoL. Although the dispersion of the shorted string was $150 \mathrm{mV}$, the maximum cell voltage remained less than $4.2 \mathrm{~V}$, and the dispersion remained stable. Even this relatively high level of dispersion had no obvious effect on the battery level results.

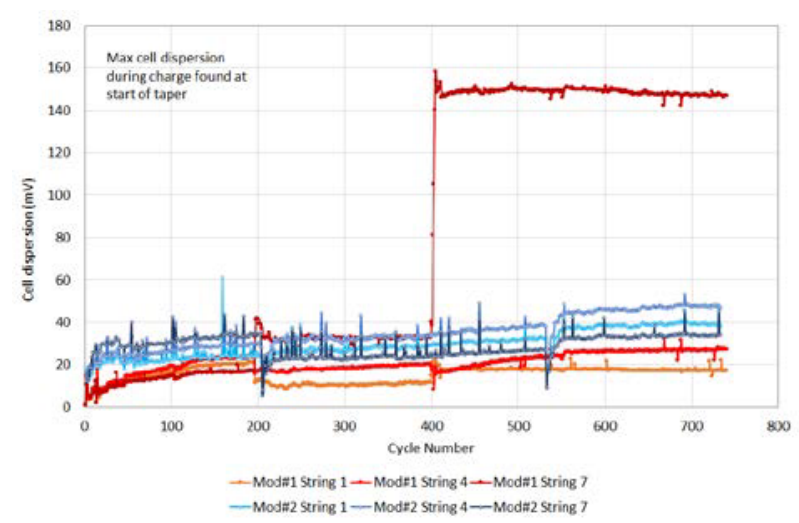

Figure 8. Cell voltage dispersion in the two modules

The average temperature of the cells in both modules at EoC is shown in Figure 9. During the life test, the average chamber temperature was around $-30^{\circ} \mathrm{C}$; the cells were warmer as the module was insulated and so retained any dissipated energy.

The average cell temperature can be seen to be between $-15^{\circ} \mathrm{C}$ and $-20^{\circ} \mathrm{C}$. This is an expected result, as the test temperature was fixed so that the coldest cell was at $-20^{\circ} \mathrm{C}$ at end of charge (EoC). However, the data show that the EoC temperature for all cells in Mod\#2 was above $-20^{\circ} \mathrm{C}$ for the majority of the test (Figure 10). This occurred because both modules were contained in the same thermal chamber. Mod\#1 was colder, with a minimum cell temperature just below $-20^{\circ} \mathrm{C}$. Therefore, the cell temperatures of Mod\#1 limited the chamber temperature, in order to ensure there was no lithium plating in either module.

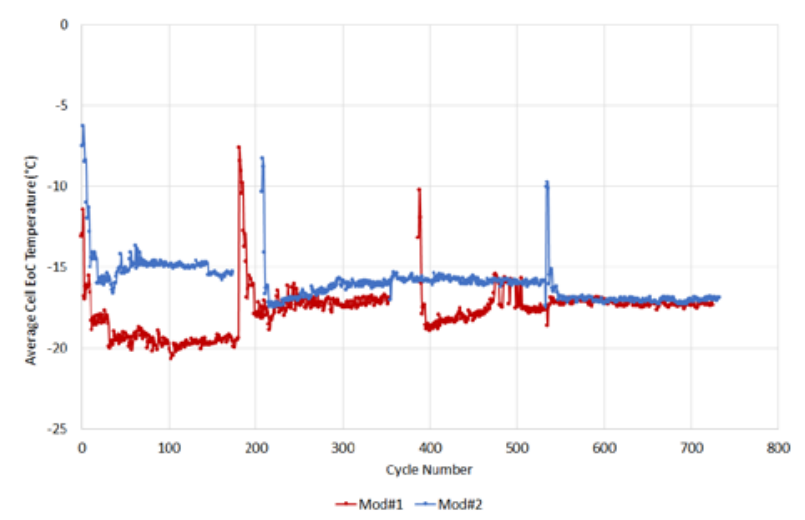

Figure 9. Comparison of module EoC temperatures

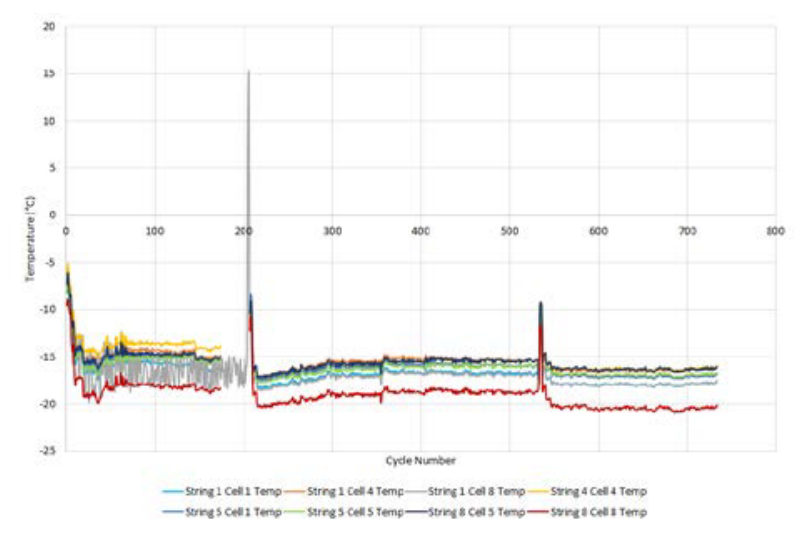

Figure 10. Mod\#2 monitored cell EoC temperatures

A comparison of the project statement of work (SoW) requirements with the results from both modules is shown in Table 3. The data shows that the modules met, or exceeded, all the requirements of this activity.

Table 3. Comparison with project requirements $\left(-20^{\circ} \mathrm{C}\right)$

\begin{tabular}{|l|c|c|c|}
\hline & SoW Req. & Mod\#1 & Mod\#2 \\
\hline EoL Energy & $200 \mathrm{Wh}$ & $432 \mathrm{Wh}$ & $467 \mathrm{Wh}$ \\
\hline EoL Energy density & $125 \mathrm{Wh} / \mathrm{kg}$ & $140 \mathrm{Wh} / \mathrm{kg}$ & $152 \mathrm{Wh} / \mathrm{kg}$ \\
\hline $\begin{array}{l}\text { Average discharge } \\
\text { voltage }\end{array}$ & $28 \mathrm{~V}$ & $28.7 \mathrm{~V}$ & $29.6 \mathrm{~V}$ \\
\hline $\begin{array}{l}\text { Lowest temperature } \\
\text { during charge }\end{array}$ & $-20^{\circ} \mathrm{C}$ & $-20^{\circ} \mathrm{C}$ & $-20^{\circ} \mathrm{C}$ \\
\hline Test duration & $720 \mathrm{Sols}$ & $720 \mathrm{Sols}$ & $720 \mathrm{Sols}$ \\
\hline
\end{tabular}

In summary, both modules completed the 720 Sol extended requirement, with $10-15 \%$ fade. The EoD voltages showed no rapid changes, which would be indicative of severe lithium plating occurring. Although Mod\#1 had a high voltage dispersion within a string due to the short circuit, the cells remained stable during subsequent cycling. The cells in Mod\#2 also stayed balanced during the 720 Sol test, with similar changes in dispersion to the non-shorted strings in Mod\#1.

\section{SURVIVABILITY TESTS}

In addition to the cycling element of the project, the battery was also required to survive an emergency case whereby the cells would be at very low temperature. This was defined as $-100^{\circ} \mathrm{C}$, to ensure the cell electrolyte was frozen.

In the previous paper, the survivability and recoverability of the cells after storage at $-100^{\circ} \mathrm{C}$ was discussed. Cells were stored at a range of states of charge (SoC) between 10 and $100 \%$ for four weeks. Testing showed these conditions had no significant impact on the cells. However, these data only showed the effect on the capacity, resistance, and 10 representative cycles. No data were available on the long term cycling performance. 
The activity was therefore extended to determine the longer term effects. The post-storage cycling requirement was increased from 10 to 180 Sols to match the original module cycling requirement. This paper describes these results.

The cycling regime was based on the module life test, with the power and voltage levels scaled to individual cell level. During the charge, the post-storage cells were charged in one stage using an average power, rather than the 14 stage regime used for the module.

The EoD voltages for the cells during the post-storage cycling is shown in Figure 11. All cells were tested individually. The results show that the EoD voltage dropped gradually throughout the test as the cells degraded. However, the 180 Sols was achieved with a large margin above the minimum voltage of $3.0 \mathrm{~V}$. The voltage difference between the cells at EoD increased during the cycling from $50 \mathrm{mV}$ at the start of the test (post freeze) to $120 \mathrm{mV}$ after the 180 cycles had been completed. This increase in the range will be due to differences in fade and/or resistance change of the cell. No link between the low temperature storage SoC and the post-storage cell cycling performance was observed.

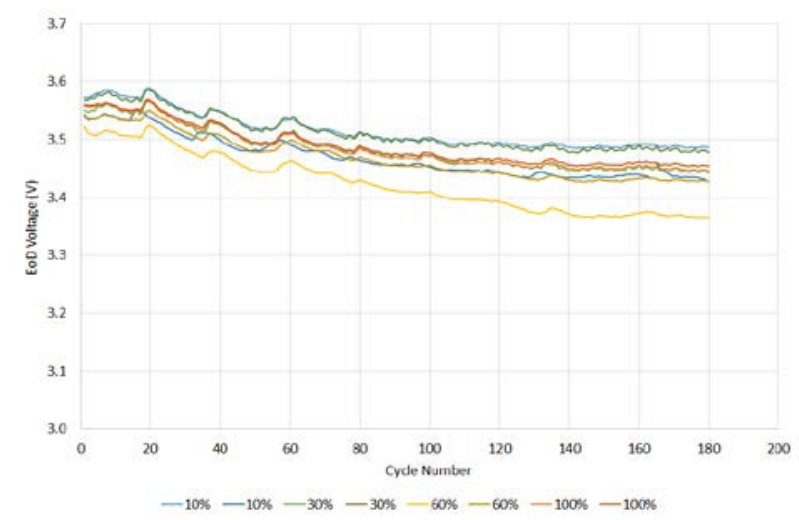

Figure 11. Cell EoDV during extended cycling at $-20^{\circ} \mathrm{C}$ (SoC refers to that during storage at $-100^{\circ} \mathrm{C}$ )

The average cell EoC voltage and the voltage range during the extended cycling test are shown in Figure 12. These values are the open circuit voltages of the cells, 30 seconds into the rest step following the charge. The voltages give an indication of how well the cells are likely to stay balanced after a freeze/thaw cycle. The data show that the EoC voltage range increased from $20 \mathrm{mV}$ (once the test was in equilibrium) up to approximately $38 \mathrm{mV}$. This result is in line with the results from the $8 \mathrm{~s} 8 \mathrm{p}$ module test at $-20^{\circ} \mathrm{C}$ which showed an increase in the dispersion of $15-20 \mathrm{mV}$ over the 180 cycles (Figure 8 ).

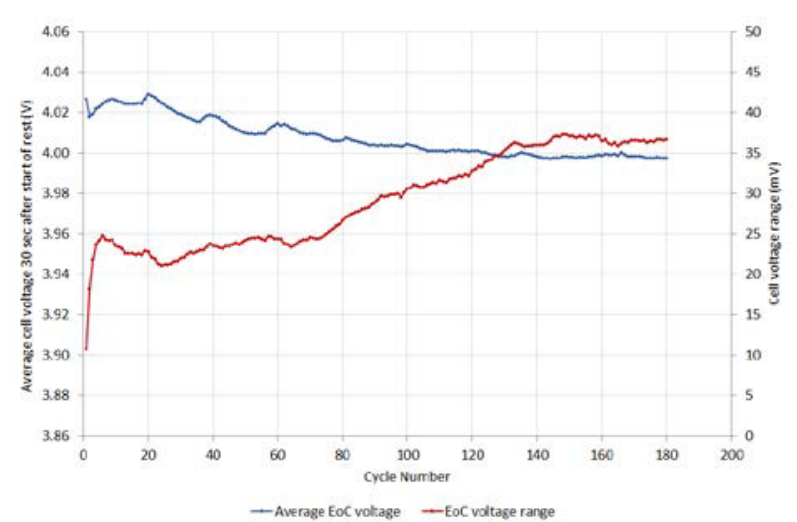

Figure 12. Average cell EoC voltage and range during extended cycling at $-20^{\circ} \mathrm{C}$

As the objective of the cycling was to determine the effect of the freeze/thaw cycling on the long term performance, it is pertinent to compare the post-storage cell voltages with the module test data. Figure 13 shows the average end of discharge voltage for the cells in the module, compared to the average value for the post-storage cells. Initially, the EoD voltage of the module is higher than that of the post-storage cells, because the module temperature was higher. At the start of the tests both thermal chambers are at $-20^{\circ} \mathrm{C}$, but because the module was insulated the cell temperature was higher than this. However, after 35 cycles the module cell temperature was at $-20^{\circ} \mathrm{C}$, so the voltages can be directly compared to the frozen/thawed cells. The difference in voltages was still maintained, implying that the cells stored at $-100^{\circ} \mathrm{C}$ may have increased in resistance during the freeze/thaw cycle. The long term decrease in the voltage also appears to be slightly higher for the cells that were stored at low temperature. However, the tests are not directly comparable as there were differences in the cycling conditions between the module and the frozen cells. The main difference was that the module used a 14 stage charge regime, whereas the cells were charged in one stage using the average power.

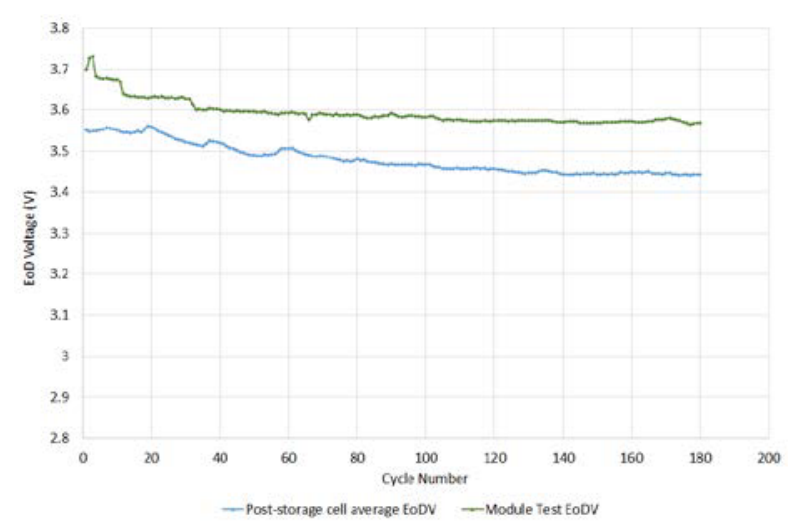

Figure 13. Comparison of EoDV during cycling after low temp storage and during module test 
Another measure of the effect of the long term storage and subsequent cycling is the change in capacity. The capacity was measured at $-20^{\circ} \mathrm{C}$, as this is representative of the capacity that would be available to a lander. The plot in Figure 14 shows that the cells faded by between $6-9 \%$ over the duration of the 180 Sol test. This result is again in-line with the results from Mod\#1, which lost $7 \%$ capacity over 180 cycles.

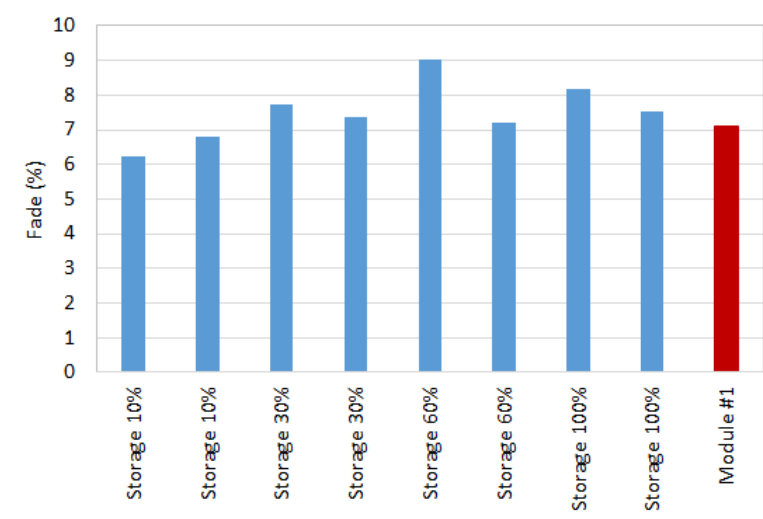

Figure 14. Capacity fade of post-storage cells after cycling at $-20^{\circ} \mathrm{C}\left(\mathrm{SoC}\right.$ refers to that during $-100^{\circ} \mathrm{C}$ storage)

In summary, cells that had been stored at $-100^{\circ} \mathrm{C}$ for 4 weeks were cycled for 180 Sols under a similar regime to the module test. The data showed that the cells were able to complete the cycling requirement, with an end of discharge voltage well above the minimum value, and that the fade and EoC voltage range were in line with the module results.

\section{BATTERY MODELLING}

An additional part of the low temperature project was the development of an electrical model to be used for general performance simulation. This has been developed for the selected cell type by performing a suite of characterisation tests. The outcome of this work has not previously been reported.

The electrical model uses a distributed nodal network that represents segments of electrode material with inter-nodal resistive links. The chosen approach allows modelling of lithium ion concentration gradients through the thickness of the electrodes. This is important for the calculation of diffusion resistance, especially under the severe rate limiting conditions seen as the temperature decreases towards $-20^{\circ} \mathrm{C}$.

In order to characterise the cell for the electrical model, testing at multiple temperatures was carried out to determine the following parameters:

\section{- EMF/SoC}

Characteristic cell open circuit voltage curve.

\section{- Internal Resistance}

Electrical resistance from tags, foils etc, as well as ionic (diffusion) resistances.

- Thermoneutral potential

Effect of temperature on the open circuit voltage.

The effect of temperature on the 'EMF' curve is shown in Figure 15. The data show large differences between the voltage curves at ambient, and those at low temperatures. These differences are more than can be explained by the thermoneutral potential. It is thought that the diffusion rates of ions through the electrodes is extremely slow, such that the current used $(\mathrm{C} / 200)$ was too fast.

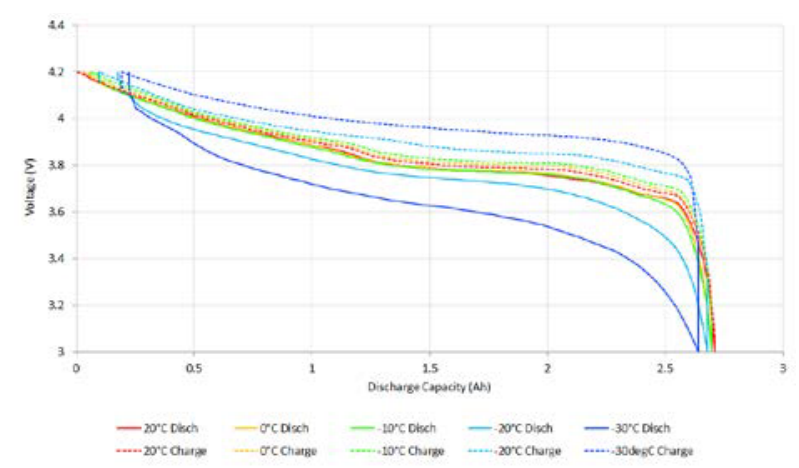

Figure 15. Measured cell 'EMF'

The plots in Figure 17 and Figure 17 show comparisons of the cell characterisation test results with the electrical model at $0^{\circ} \mathrm{C}$ and $-20^{\circ} \mathrm{C}$, respectively. The model matches the experimental data well at $0^{\circ} \mathrm{C}$. As the temperature is decreased to $-20^{\circ} \mathrm{C}$, the slow diffusion within the electrodes limits the rate at which the cells can charge/discharge, and the modelling becomes more challenging.



Figure 16. Comparison of test and model results at $0^{\circ} \mathrm{C}$ 




Figure 17. Comparison of test and model results at $-20^{\circ} \mathrm{C}$

A comparison between the electrical model, and the measured data from Mod\#1 (once equilibrium was gained), are shown in Figure 18. Although the EoD voltages are a reasonable match, the model does not follow the voltage during the taper charge very well. The life test module remains at the maximum taper voltage for all charge steps except for the last one, whereas the model shows the voltage dropping almost from the start of the charge. This is likely to be due to different diffusion behaviour within the cells that the model was based on (single cells), and those within an insulated module. In addition, the electrical model cannot take account of the complex thermal behaviour within the module, for example cell-to-cell gradients.



Figure 18. Comparison of model voltage with module life test results

In summary, the low temperature conditions utilised for this project were challenging to model due to low diffusion rates within the electrode having a large effect on the 'resistance' and available capacity. Although there are clearly limitations on the accuracy of the model, the simulation is on the edge of the feasible cell operational window, where the cells' rate capability displays extremely high sensitivity to temperature. However, the simulation results have managed to capture the overall behaviour reasonably.

\section{DEVELOPMENT PLAN}

Following this testing, it is the view of ABSL that the technology (i.e. the selected cell type for use in low temperature space applications) is currently at TRL4, approaching TRL5. A plan has therefore been developed to increase the TRL to 7 .

An overview of the proposed route from TRL4 to TRL7 is shown in Figure 5. The green squares represent complete or partially complete activities, the blue squares represent tests that are ongoing, but may need to be repeated depending on updated power profiles.



Figure 19. Development Plan

To move from the current position to TRL5, the initial stages of cell qualification should be completed, such that the cell performance in all areas can be confirmed. For example, the cell survival in typical space conditions (vacuum, radiation) and to launch (vibration testing) would need to be confirmed.

To achieve TRL6, further qualification work would be required, so that a fully representative prototype battery can be designed and manufactured. This would include testing to determine spot weld settings, and to obtain data for piece part manufacture.

Finally, to achieve TRL7, a prototype would be manufactured and tested using a standard flight battery process and levels. This would then be delivered for integration into the Martian lander for system level testing prior to launch.

\section{CONCLUSIONS AND FURTHER WORK}

Work has been undertaken to develop a secondary Liion battery from Commercial-off-the-Shelf (COTS) 
cells than operate at temperatures below $-20^{\circ} \mathrm{C}$. A previous paper [1] described the search for a suitable cell, and showed the data from the initial module test.

This paper presented the results from the extended module life test. An $8 \mathrm{~s} 8 \mathrm{p}$ module of COTS cell has now successfully completed 720 Sols under a representative Martian lander power profile.

In addition, the long term effects of cycling after very low temperature storage were presented. Even after these extreme storage conditions, the cell completed the required 180 Sols.

The final part of the project was to produce a performance model of the cells.

A plan has been developed for developing the TRL of this technology to a level suitable for space applications.

\section{ACKNOWLEDGEMENTS}

This work was performed within the project Development of a Low Temperature Lithium Ion Battery and Survivability Tests. The authors want to thank the European Space Agency for funding this project through ESA's Mars Robotic Exploration Preparation (MREP) Programme.

\section{REFERENCES}

1. Buckle, R., Thwaite, C., Vijendran, S., Schautz, M.; A Low Temperature Li-ion Battery for Mars Landers based on COTS Cells; 10th European Space Power Conference, Noordwijkerhout, The Netherlands, 13-17 April 2014

2. Future Power Systems for Space Exploration: Executive Summary; ESTEC/Contract No. $14565 / 00 / \mathrm{NL} / \mathrm{WL}$

3. ESA; SOW: Development of a Low Temperature Lithium Ion Battery and Survivability Tests, Issue $1,01 / 09 / 2010$ 